Reprinted with permission from: Weed Technology. 1999. Volume 13:835-839.

Published and copyrighted by: Weed Science Society of America. http://www.wssa.net

\title{
Influence of deleterious rhizobacteria on leafy spurge (Euphorbia esula) roots ${ }^{1}$
}

\author{
MARK A. BRINKMAN, SHARON A. CLAY, and ROBERT J. KREMER \\ Former Postdoctoral Associate, Professor, and Microbiologist, Plant Science Department, South Dakota state Univer- \\ sity, Brookings, SD 57007, and USDA-ARS Cropping Systems and Water Quality Unit, University of Missouri, Colum- \\ bia, MO 65211. Current address of senior author: Department of Entomology, University of Georgia Agricultural \\ Experiment Station, Griffin, GA 30223. Corresponding author's E-mail: sharon_clay@sdstate.edu.
}

\begin{abstract}
:
Rhizobacteria have been shown to be phytotoxic to leafy spurge in laboratory assays. This field study investigated the influence of two strains of Pseudomonas fluorescens [Trevisan, (Migula)], deleterious rhizobacteria (DRB), on root weight, root bud number, and root carbohydrate content of leafy spurge at three sites located in northeast and north-central South Dakota. Soils were inoculated with $2 \mathrm{~g}$ of starch-based granules containing no bacteria or starch granules containing $10^{8}$ colony-forming units (cfu)/g of either bacterial strain LS102 (Montana origin) or LS174 (South Dakota origin). Bacterial strains were detected on root samples from treated areas. Root weight and root carbohydrate content were reduced about $20 \%$ compared to roots from control plots.
\end{abstract}

Nomenclature:

Leafy spurge, Euphorbia esula L. \#² EPHES; deleterious rhizobacteria, Pseudomonas fluorescens [Trevisan, (Migula)].

\section{Additional index words:}

Total nonstructural carbohydrates.

\footnotetext{
${ }^{1}$ Received for publication April 30, 1999, and in revised form September 13, 1999. South Dakota State University Experiment Station Paper 3121. Mention of trade names does not constitute an endorsement by the USDA-ARS, South Dakota State University, or the University of Missouri over other products not mentioned.

${ }^{2}$ Letters following this symbol are a WSSA-approved computer code from Composite List of Weeds, Revised 1989. Available only on computer disk from WSSA, 810 East $10^{\text {th }}$ Street, Lawrence, KS 66044-8897.
} 


\section{Abbreviations:}

Cfu, colony-forming units; DRB, deleterious rhizobacteria; SR, SandsRovira; TNC, total nonstructural carbohydrates, EPHES.

\section{Introduction}

Leafy spurge is a noxious weed that reproduces asexually from root and crown buds and from seed (Luster and Farrell 1996). Leafy spurge reduces rangeland productivity by competing with desirable forage species and causing illness in livestock. Annual losses due to leafy spurge have been estimated to be over $\$ 120$ million (Bangsund 1991; Watson, 1985). Herbicide treatments are expensive, and retreatment is necessary over several years to maintain acceptable control. Herbicides that provide the best control of leafy spurge have application restrictions that limit their use in ecologically sensitive sites.

Biotic agents have been used as an alternative or supplemental management tactic for herbicide use in leafy spurge. Biological control of leafy spurge has focused primarily on root-feeding insects. At least six species of Aphthona flea beetle have been introduced to North America (Julien and Griffiths 1998). Aphthona nigriscutis Foudras (Coleoptera: Chrysomelidae) has established and dramatically reduced leafy spurge infestations in some upper Great Plains habitats (Rees et al. 1996). However, it often takes several years for a flea beetle population to grow to sufficient size to affect a leafy spurge infestation at a particular site. The integration of additional biotic agents with the flea beetle may increase leafy spurge control and reduce the time necessary to noticeably decrease infestations.

Biotic agents that may be compatible with flea beetles include specific soilborne fungal (Caesar 1996; Caesar et al. 1993) and bacterial (Caesar 1994) pathogens and DRB. The biocontrol tactic based on use of DRB delivers selected nonparasitic bacteria that colonize plant roots and suppress plant growth (Kennedy et al. 1991; Kremer et al. 1990; Kremer and Kennedy 1996). Several strains of $P$. fluorescens have been isolated from leafy spurge roots and are phytotoxic and host-specific toward leafy spurge calli and seedlings in laboratory and greenhouse assays (Souissi and Kremer 1994). The objective of this study was to determine if selected strains of DRB collected from leafy spurge infestations in South Dakota and Montana could colonize and influence plant growth under field conditions.

\section{Materials and methods}

\section{Experimental sites}

Experiments with DRB strains were conducted at three South Dakota sites infested with leafy spurge. Two sites were located in Marshall County (near Britton) about $15 \mathrm{~km}$ apart, in the dry subhumid region of northeastern South Dakota. The third site was lo- 
cated in Campbell County (near Pollock) in the north-central region at the margin of dry subhumid and semi-arid regions. Soil characteristics of the sites are presented in Table 1. To standardize treatment application and sampling area, 15-cm-diam polyvinyl chloride rings were placed around leafy spurge shoots and inserted into the ground to a depth of about $10 \mathrm{~cm}$. The rings were placed at random in the spurge-infested areas with 12 rings per replicate.

Table 1. Selected soil properties at two sites in Marshall County and one site in Campbell County, South Dakota.

\begin{tabular}{|c|c|c|c|c|c|c|}
\hline Site & Soil classification & Sand & Silt & Clay & Organic matter & Soil $\mathrm{pH}$ \\
\hline & & 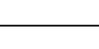 & $-\%$ & 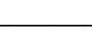 & & \\
\hline \multicolumn{7}{|l|}{ Marshall } \\
\hline Site 1 & Forman ${ }^{\mathrm{a}}$ Aastad $^{\mathrm{b}}$ loam & 38.7 & 38.5 & 22.8 & 10.4 & 5.8 \\
\hline Site 2 & Forman-Aastad loam & 35.4 & 36.7 & 27.9 & 8.3 & 5.8 \\
\hline Campbell County & Sully $^{\mathrm{c}}$ silt loam & 19.0 & 67.4 & 13.6 & 4.0 & 7.5 \\
\hline
\end{tabular}

${ }^{\mathrm{a}}$ Forman taxonomic series: fine-loamy, mixed, superactive Argiborolls.

${ }^{\mathrm{b}}$ Aastad taxonomic series: fine-loamy, mixed superactive Pachic Udic Haploborolls.

${ }^{\mathrm{c}}$ Sully taxonomic series: coarse-silty, mixed calcareous, mesic Typic Ustorthents.

\section{DRB Treatments}

Two DRB strains originally collected from roots of leafy spurge in Montana (LS102) and South Dakota (LS174) were used in this study. Both strains were identified as $P$. fluorescens using the API 20NE test system with verification by fatty acid methyl ester analyses as described previously (Souissi and Kremer 1994). These strains also severely inhibited leafy spurge growth in greenhouse assays (Souissi et al. 1997). Antibioticresistant mutants of each strain were selected on Sands-Rovira (SR) medium (Sands and Rovira 1970) containing $80 \mu \mathrm{g} / \mathrm{g}$ rifampicin and $100 \mu \mathrm{g} / \mathrm{g}$ nalidixic acid. This enabled detection of the isolates after inoculation of leafy spurge by culturing field samples on media containing the antibiotics that inhibited growth of indigenous soil and rhizosphere microorganisms.

For inoculum production, DRB strains were cultured in SR broth on a rotary shaker $(140 \mathrm{rpm})$ at $27^{\circ} \mathrm{C}$ for 48 hours. Cultures were centrifuged $(1,800 \mathrm{~g})$ at $5^{\circ} \mathrm{C}$, and the supernatant was discarded. The concentrated cells were resuspended in about $25 \mathrm{ml}$ fresh SR broth. A starch-based granular inoculant was prepared by blending the resuspended cells with $100 \mathrm{~g}$ semolina flour (Connick et al. 1991) to achieve about $10^{8} \mathrm{cfu}$ of bacteria per gram of granules. Inoculant granules were air dried at room temperature for 12 hours, dispensed in sterile plastic bags, and stored at $8^{\circ} \mathrm{C}$ until use.

Treatments consisted of $2 \mathrm{~g}$ of starch-based inoculant containing no DRB (blank controls), DRB LS102, or LS174. Inoculant treatments were incorporated to a soil depth of about $3 \mathrm{~cm}$ using a small hoe. Treatments were applied initially on May 19 at the Marshall County sites and on June 12 at the Campbell County site in 1995. In 1996, a second 
treatment was applied on June 14 and June 12 at the Marshall and Campbell sites, respectively.

\section{Root collection and analyses}

Twelve rings per treatment that contained the intact soil core and roots were excavated with a spade at each site in mid-September 1995, in mid-May 1996 (prior to second inoculation), and in mid-September 1996. Samples were placed in $3.8 \mathrm{~L}$ plastic bags and stored at $4^{\circ} \mathrm{C}$.

Roots from rings were weighed, and the number of buds on roots was recorded. A $3.5-\mathrm{cm}$ section of leafy spurge root and $20 \mathrm{~g}$ of soil were removed from each ring sample and tested for viable DRB. Root segments were shaken free of soil and placed in test tubes containing $10 \mathrm{ml}$ of $0.1 \mathrm{M} \mathrm{MgSO}_{4} \cdot 7 \mathrm{H}_{2} \mathrm{O}$, and the tubes were agitated on a vortex mixer for 5 minutes. The resulting root washings were serially diluted five times in 10fold steps and plated on SR agar medium containing rifampicin $(80 \mu \mathrm{g} / \mathrm{ml})$ and nalidixic acid $(100 \mu \mathrm{g} / \mathrm{ml})$. Plates were incubated in the dark at $28^{\circ} \mathrm{C}$ for 5 days, after which bacterial colonies were counted. Inoculant DRB were not only detected by ability to grow on the antibiotic-amended culture medium but also based on distinctive characteristics including opaque, glistening, elevated, and entire colony morphology. Also, no indigenous bacteria from roots were detected that were able to grow on the antibiotic medium used in the study. Colonization was expressed as the number of colony-forming units per gram root.

Carbohydrate analyses (Smith 1981) were conducted on three to five separate 5-cm root sections from each ring. Each root section was washed, cut into $\leq 2-\mathrm{mm}$ pieces, dried for 24 hours at $70^{\circ} \mathrm{C}$, and then fine ground using mortar and pestle. A 0.1 -g sample was weighed and placed in a 125-ml Erlenmeyer flask. About $15 \mathrm{ml}$ of distilled water was added to each flask and boiled for 5 minutes. Samples were allowed to cool to room temperature before addition of $10 \mathrm{ml}$ of buffer solution and $10 \mathrm{ml}$ of $0.5 \%$ amyloglucosidase enzyme. Flasks were stoppered and incubated 24 hours at $38^{\circ} \mathrm{C}$. After filtration through Whatman No. 1 paper into $100-\mathrm{ml}$ volumetric flasks, the solution was treated with $2 \mathrm{ml}$ of $10 \%$ neutral lead acetate and brought to volume with distilled water. The solution was returned to $125-\mathrm{ml}$ Erlenmeyer flasks, stoppered, shaken vigorously, and allowed to precipitate.

A solution to measure the reducing power of the root solution (Reagent " 50 ") was prepared. One liter of Reagent " 50 " contained $25 \mathrm{~g}$ of anhydrous sodium carbonate, $25 \mathrm{~g}$ of sodium potassium tartarate, $75 \mathrm{ml}$ of $10 \%$ copper sulfate, $20 \mathrm{~g}$ of sodium bicarbonate, $1 \mathrm{~g}$ of potassium iodide, and $200 \mathrm{ml}$ of potassium iodate solution containing $3.567 \mathrm{~g}$ of pure $\mathrm{K} 10_{3} / \mathrm{L}$, which was brought up to volume with distilled water (Smith 1981). A 10-ml aliquot of sample and $10 \mathrm{ml}$ of Reagent " 50 " were added to a test tube, and boiled for 15 minutes. Test tubes were removed and immediately placed in a cool water bath. Standards were prepared with $10 \mathrm{ml}$ Reagent "50," $3 \mathrm{mg}$ sugar, and 10-ml enzyme samples. Potassium iodide-potassium oxalate solution $(2 \mathrm{ml})$ was added to each test tube followed 
by $10 \mathrm{ml}$ of $1.0 \mathrm{~N} \mathrm{H}_{2} \mathrm{SO}_{4}$. Samples were then analyzed using a Mettler DL21 titrator ${ }^{3}$ with the addition of $0.02 \mathrm{~N}$ sodium thiosulfate. The amount of sugar in samples was calculated using titration data in the formula:

$3 \mathrm{mg}$ sugar/(Reagent “50” - glucose standard) (enzyme - sample) = mg glucose.

The percentage total nonstructural carbohydrate (TNC) in tissue was determined using the formula:

Percentage $\mathrm{TNC}=(\mathrm{mg}$ glucose - dilution factor of $100 \bullet 100) /$ sample weight in $\mathrm{mg}$.

\section{Data analyses}

ANOVA procedures in SAS (1989) were applied to the data. Means were compared using the LSD test at $\mathrm{P}=0.05$.

\section{Results and discussion}

Colonies of the antibiotic-resistant DRB mutants were recovered on SR media amended with rifampicin plus nalidixic acid only from roots in areas receiving inocula that contained LS102 or LS174. No colonies were recovered on the antibiotic-amended media from control rings. Relative root colonization levels by both DRB isolates at the fall 1995 and spring 1996 samplings were higher at the Marshall sites than at the Campbell site (Table 2). The contrast in root colonization by both strains among sites may be related to differences in soil properties (Table 1). The loam soils at the Marshall sites were lower in $\mathrm{pH}$ and had more organic matter compared to soil from the Campbell site. The slightly acid $\mathrm{pH}$ combined with high organic matter may have favored proliferation of DRB in the leafy spurge rhizosphere, similar to responses of rhizosphere bacteria in general (Curl and Truelove 1986). Soils with clay content also have been reported to favor rhizobacteria activity (Stutz et al. 1989).

Table 2. Colonization of leafy spurge roots by Pseudomonas fluorescens strains LS 102 and LS 174 expressed as the number of colony-forming units (cfu) at three South Dakota sites in fall 1995 and spring and fall 1996. No evidence of colonization was present in plots inoculated with untreated starch granules.

\begin{tabular}{|c|c|c|c|c|c|c|}
\hline \multirow[b]{2}{*}{ Site } & \multicolumn{3}{|c|}{ LS 102} & \multicolumn{3}{|c|}{ LS 174} \\
\hline & Fall 1995 & Spring $1996^{\mathrm{a}}$ & Fall 1996 & Fall 1995 & Spring 1996 & Fall 1996 \\
\hline & & & $\mathrm{cfu}$ & $0^{3}$ & & \\
\hline \multicolumn{7}{|l|}{ Marshall County } \\
\hline Site 1 & $89.0(1.5)^{b}$ & $22.2(7.2)$ & $0.5 \quad(0.02)$ & $22.0(1.1)$ & $2.4(0.6)$ & $0.9(0.12)$ \\
\hline Site 2 & $28.0(4.1)$ & $6.3(0.6)$ & $0.37(0.02)$ & $28.5(0.8)$ & $16.2(7.0)$ & $1.0(0.08)$ \\
\hline Campbell County & $19.2(1.5)$ & $0.2(0.02)$ & $0.30(0.07)$ & $12.5(1.7)$ & $0.2(0.01)$ & $0.4(0.06)$ \\
\hline
\end{tabular}

${ }^{3}$ Mettler DL21 titrator, Mettler Instrument Corp., Box 71, Highstown, NJ 08520. 
Despite the repeated application of inocula in spring 1996, assays of roots collected in fall 1996 had relatively low concentrations of both DRB strains at all sites (Table 2). Fluctuations in soil moisture and temperature directly affect colonization of host plant roots by DRB as well as survival in soil (Johnson et al. 1993). Temperatures in both years were similar; however, rainfall amounts and patterns differed between years (Table 3). Rainfall in 1995 at the two Marshall sites totaled $12.6 \mathrm{~cm}$ for June and July. In 1995, the Campbell site received about $12.5 \mathrm{~cm}$. of rain during June and another $8.3 \mathrm{~cm}$ of rain in July. The timely rains most likely helped dissolve the starch granules and move the DRB into favorable colonization sites soon after application. In 1996, rainfall in June and July at the Marshall and Campbell sites totaled about 9.6 and $7.5 \mathrm{~cm}$, respectively. These drier conditions may not have been favorable for DRB survival. Adjusting the components of the formulation by adding small amounts of specific sugars, amino acids, or other starches known to stabilize bacterial viability (Caesar and Burr 1991) may aid in increasing survival of the applied DRB in soil.

Location and sampling date did not influence root weight or bud number, so data were averaged across these variables. Root weight was reduced about 25\% by LS102 and $10 \%$ by LS174, whereas number of buds was unaffected (Table 3). LS102 and LS174 reduced leafy spurge root growth as well as shoot bud numbers in previous greenhouse studies (Souissi et al. 1997). Other studies have reported DRB to reduce root fresh weight (Nehl et al. 1997).

Table 3. Precipitation amounts in 1995 and 1996 and the 30-yr normal (1961-1990) from weather stations near the experimental sites. The closest reporting stations to the Marshall County and Campbell County sites were Britton and Pollock, SD, respectively. Reporting stations were within $20 \mathrm{~km}$ of the experimental sites.

\begin{tabular}{|c|c|c|c|c|c|c|c|c|c|c|c|c|c|}
\hline & Jan. & Feb. & March & April & May & June & July & Aug. & Sept. & Oct. & Nov. & Dec. & Total \\
\hline \multicolumn{14}{|c|}{ Marshall County (Britton) } \\
\hline 1995 & 2.5 & 0.7 & 7.5 & 4.5 & 6.8 & 6.1 & 6.5 & 10.4 & 11.6 & 7.6 & 1.5 & 1.0 & 66.7 \\
\hline 1996 & 3.0 & 1.2 & 2.0 & 1.0 & 11.1 & 5.1 & 4.5 & 1.8 & 9.1 & 6.6 & 3.5 & 1.2 & 50.0 \\
\hline 30-yr normal & 1.1 & 1.3 & 3.1 & 5.2 & 7.0 & 8.4 & 7.3 & 6.3 & 4.9 & 3.6 & 1.8 & 1.1 & 51.2 \\
\hline \multicolumn{14}{|c|}{ Campbell County (Pollock) } \\
\hline 1995 & 0.4 & 1.7 & 2.4 & 4.5 & 10.4 & 12.5 & 8.3 & 3.4 & 2.3 & 7.5 & 1.5 & 0.9 & 55.9 \\
\hline 1996 & 1.3 & 0.8 & 1.5 & 1.0 & 11.4 & 5.4 & 2.1 & 4.0 & 10.8 & 4.7 & 3.3 & 2.7 & 49.0 \\
\hline 30-yr normal & 0.8 & 1.1 & 2.8 & 5.3 & 6.7 & 8.1 & 5.8 & 5.1 & 3.6 & 2.8 & 1.3 & 1.1 & 44.4 \\
\hline
\end{tabular}

Leafy spurge carbohydrate levels varied over time. Roots removed in spring 1996 contained 30\% less TNC than roots from either of the fall samplings (data not shown). Lym and Messersmith (1987) studied seasonal variation in leafy spurge root carbohydrate content and reported lowest levels in early spring. The mean carbohydrate content of 
roots from control plots in our study averaged about $220 \mathrm{mg} / \mathrm{g}$ (Table 4). Both strains of DRB reduced the carbohydrate content of leafy spurge roots by about $20 \%(\mathrm{P}=0.0345)$.

The mechanisms by which DRB reduce carbohydrate content of leafy spurge roots have not been determined; however, multiple mechanisms were likely involved. High populations of rhizosphere bacteria can cause ultrastructural damage to root cells and lead to cellular leakage (Curl and Truelove 1986). LS102 has been reported to cause cell membrane disruption of leafy spurge root cells that may lead to a reduction of root constituents including carbohydrates (Souissi et al. 1997). The isolates used in this study also have been reported to produce phytotoxic levels of auxins and other phytotoxic chemicals in leafy spurge seedlings (Souissi and Kremer 1994). Phytotoxins produced by rhizobacteria may reduce cell membrane integrity, macromolecule synthesis, and metabolism (Nehl et al. 1997; Tranel et al. 1993). This may be manifested in leafy spurge roots as reduced carbohydrate concentration. High auxin content also inhibits root growth and may repress metabolism in the root (Sarwar and Kremer 1995).

Table 4. The effect of deleterious rhizobacteria isolates LS 102 and LS 174 on mean weight of leafy spurge roots, number of buds, and nonstructural carbohydrates averaged over three South Dakota sites.

\begin{tabular}{lccc}
\hline Treatment & Root weight & Root buds & $\begin{array}{c}\text { Nonstructural } \\
\text { Carbohydrate content }\end{array}$ \\
\hline & $\mathrm{mg} / \mathrm{cm}^{3}$ of soil & No./mg root & $\mathrm{mg} / \mathrm{g}$ \\
Control & $2.53(0.34)^{\mathrm{a}}$ & $3.0(0.9)$ & $220(15)$ \\
LS102 & $1.84(0.25)$ & $2.9(0.7)$ & $170(13)$ \\
LS174 & $2.12(0.27)$ & $2.7(0.5)$ & $183(15)$ \\
\hline
\end{tabular}

${ }^{\mathrm{a}}$ Numbers in parentheses are the $95 \%$ confidence interval of the mean.

The depletion of carbohydrate root reserves may be an important mechanism of action for DRB. Perennial weeds rely on root carbohydrate reserves both for winter survival and for rapid regrowth in the spring. Depletion of root carbohydrate reserves by imposing stress via cultural practices or exposure to biocontrol agents may increase leafy spurge winterkill. (Lym and Messersmith 1987, 1993).

\section{Acknowledgment}

Financial support from the South Dakota Weed and Pest Commission is gratefully acknowledged.

\section{Literature cited}

Bangsund, D. A. 1991. Economic Impact of Leafy Spurge in Montana, South Dakota, and Wyoming. North Dakota State University Agricultural Economic Rep. 275. 85 p.

Caesar, A. J. 1994. Pathogenicity of Agrobacterium species from the noxious rangeland weeds Euphorbia esula and Centaurea repens. Plant Dis. 78: 796-800.

Caesar, A. J. 1996. Identity, pathogenicity, and comparative virulence of Fusarium spp. related to stand declines of leafy spurge in the Northern Plains. Plant Dis. 80:1395-1398.

Page 7 of 8 
Caesar, A. J. and T J. Burr 1991. Effect of conditioning, betaine, and sucrose on survival of rhizobacteria in powder formulations. Appl. Environ. Microbiol. 57:168-172.

Caesar, A. J., N. E. Rees, N. R. Spencer, and P C. Quimby, Jr. 1993. Characterization of Rhizoctonia spp. causing diseases of leafy spurge in the Northern Plains. Plant Dis. 77:681-684.

Connick, W. J., C. D. Boyette, and J. R. McAlpine. 1991. Formulation of mycoherbicides using a pasta-like process. Biol. Control 1:281-287.

Curl, E. A. and B. Truelove. 1986. The Rhizosphere. Berlin: Springer-Verlag. 288 p.

Johnson, B. N., A. C. Kennedy, and A. G. Ogg, Jr. 1993. Suppression of downy brome growth by a rhizobacterium in controlled environments. Soil Sci. Soc. Am. J. 57:73-77.

Julien, M. H. and M. W. Griffiths. 1998. Biological Control of Weeds: A World Catalogue of Agents and Their Target Weeds. 4th ed. Oxford, UK: CAB International. 223 p.

Kennedy, A. C., L. F. Elliott, F. L. Young, and C. L. Douglas. 1991. Rhizobacteria suppressive to the weed downy brome. Soil Sci. Soc. Am. J. 55: 722-727.

Kremer, R. J., M.F.T. Begonia, L. Stanley, and E. T. Lanham. 1990. Characterization of rhizobacteria associated with weed seedlings. Appl. Environ. Microbiol. 56:1649-1655.

Kremer, R. J. and A. C. Kennedy. 1996. Rhizobacteria as biological control agents of weeds. Weed Technol. 10:601-609.

Luster, D. G. and H. M. Farrell, Jr. 1996. Seasonal expression patterns and characterization of a Euphorbia esula root storage protein. Plant Physiol. Biochem. 34:111-118.

Lym, R. G. and C. G. Messersmith. 1987. Carbohydrates in leafy spurge roots as influenced by environment. J. Range Manage. 40:139-144.

Lym, R. G. and C. G. Messersmith. 1993. Fall cultivation and fertilization to reduce winter hardiness of leafy spurge (Euphorbia esula). Weed Sci. 41: 441-446.

Nehl, D. B., S. J. Allen, and J. F Brown. 1997. Deleterious rhizosphere bacteria: an integrating perspective. Appl. Soil Ecol. 5:1-20.

Rees, N. E., N. R. Spencer, L. V. Knutson, L. Fornasari, P. C. Quimby, Jr., R. W. Pemberton, and R. M. Nowierski. 1996. Spurges. In N. E. Rees, P. C. Quimby, Jr., E. M. Coombs, E. E. Turner, N. R. Spencer, and L. V. Knutson, eds. Biological Control of Weeds in the West. Bozeman, MT Western Society of Weed Science.

Sands, D. C. and A. D. Rovira. 1970. Isolation of fluorescent pseudomonads with a selective medium. Appl. Microbiol. 20:513-514.

Sarwar, M. and R. J. Kremer. 1995. Enhanced suppression of plant growth through production of Ltryptophan-derived compounds by deleterious rhizobacteria. Plant Soil 172:261-269.

[SAS] Statistical Analysis Systems. 1989. SAS/STAT User's Guide. Vers. 6, 4th ed. Cary, NC: Statistical Analysis Systems Institute.

Smith, D. 1981. Removing and Analyzing Total Nonstructural Carbohydrates from Plant Tissue. University of Wisconsin Research Rep. 2107. p. 5.

Souissi, T. and R. J. Kremer. 1994. Leafy spurge (Euphorbia esula) cell cultures for screening deleterious rhizobacteria. Weed Sci. 42:310-315.

Souissi, T. R. J. Kremer, and J. A. White. 1997. Scanning and transmission electron microscopy of root colonization of leafy spurge (Euphorbia esula L.) seedlings by rhizobacteria. Phytomorphology 47:177-193.

Stutz, E. W., G. Kahr, and G. DeFago. 1989. Clays involved in suppression of tobacco black rot by a strain of Pseudomonas fluorescens. Soil Biol. Biochem. 21:361-366.

Tranel, P. J., D. R. Gealy, and G. R. Irzyk. 1993. Physiological responses of downy brome (Bromus tectorum) roots to Pseudomonas fluorescens strain D7 phytotoxin. Weed Sci. 41:483-489.

Watson, A. K. 1985. The leafy spurge problem. In A. K. Watson, ed. Leafy Spurge. Champaign, IL: Weed Science Society of America. pp. 1-6.

Page 8 of 8 